\title{
PENGARUH PERMAINAN EDUKATIF DENGAN PERKEMBANGAN SOSIAL ANAK PRASEKOLAH USIA 3-4 TAHUN
}

\author{
Nyna Puspita Ningrum, Damarati Azaria \\ Tenaga Pengajar Prodi DIII Kebidanan, Universitas PGRI Adi Buana Surabaya
}

\begin{abstract}
ABSTRAK
Permainan edukatif merupakan permainan yang sangat memberikan fungsi permainan secara optimal dan perkembangan anak, dimana melalui alat permainan ini akan selalu mengembangkan kemampuan fisiknya, bahasa, kemampuan kognitifnya, dan adaptasi sosialnya (Alimul, 2005). Kebutuhan stimulasi atau upaya merangsang anak dengan menggunakan permainan edukatif untuk memperkenalkan suatu pengetahuan ataupun ketermpilan baru ternyata sangat penting dalam upaya peningkatan kecerdasan anak (Siswono, 2004). Tujuan umum dari penelitian ini adalah untuk mengetahui pengaruh permainan edukatif dengan perkembangan sosial anak prasekolah usia 3-4 tahun. Desain penelitian ini menggunakan desain korelasi product moment, dengan populasi seluruh anak usia 3-4 tahun di PAUD Permata Hati bulan juni 2013 sebanyak 23 responden. Pengambilan sampel dengan total sampling dan instrumen penelitian yaitu APE dan ceklist. Hasil analisis data menggunakan korelasi product moment dengan taraf signifikasi sebesar 0,05 di dapatkan r-hitung sebesar 0,828 dan r-tabel 0,413 (diperoleh $r$-hitung $>r$-tabel). Berdasarkan hasil penelitian diperoleh data bahwa responden yang mampu melakukan permainan edukatif sesuai perintah dan berperilaku sosial sebanyak 9 responden $(39,2 \%)$, sedangkan anak yang cukup mampu melakukan permainan edukatif sesuai perintah dan berperilaku sosial sebanyak 6 responden (26,1\%). Dari hasil perhitungan menggunakan korelasi product moment didapatkan hipotesis diterima, maka dapat disimpulkan bahwa ada pengaruh permainan edukatif dengan perkembangan sosial anak prasekolah usia 3-4 tahun di PAUD Permata Hati Sidoarjo tahun 2013. Dari hasil penelitian ini disarankan kepada orang tua, pengasuh dan tenaga pengajar lebih memperhatikan pemilihan dan penggunaan alat permainan yang digunakan anak didiknya, sehingga saat anak bermain sekaligus dapat melatih perkembangan anak pra sekolah khususnya kemampuan berbicara, berbahasa serta sosialisasi dan kemandirian.
\end{abstract}

Kata Kunci : Permainan edukatif, Perkembangan Sosial Anak prasekolah.

\section{PENDAHULUAN}

Tiap orang tua menginginkan putraputrinya mengalami pertumbuhan dan perkembangan yang optimal. Proses tumbuh kembang anak di pengaruhi banyak faktor secara garis besar terbagi dua faktor yaitu faktor Genetik dan Biofisiko psikososial. Dalam proses tersebut anak memerlukan pemenuhan kebutuhan dasar anak, yaitu pertumbuhan asuh (biomedis), asih (kebutuhan emosi dan kasih sayang), dan asah (pemberian rangsang). Tiga tahun pertama usia perkembangan anak merupakan periode emas/masa kritis untuk optimalisasi proses tumbuh kembang dan merupakan masa yang tepat untuk seorang anak.
Dari umur 2 sampai 6 tahun anak belajar melakukan hubungan sosial dan bergaul dengan orang-orang diluar lingkungan rumah, terutama dengan anak-anak yang umurnya sebaya. Mereka belajar menyesuaikan diri dan bekerja sama dalam kegiatan bermain. Masa kanakkanak adalah sejumlah hubungan yang dilakukan anak dengan anak-anak yang lain meningkat dan ini untuk menentukan bagaimana gerak maju perkembangan sosial mereka. (Elizabeth B Hurlock, 2002). Kebutuhan stimulasi atau upaya merangsang anak dengan menggunakan permainan edukatif untuk memperkenalkan suatu pengetahuan ataupun ketermpilan baru ternyata sangat penting dalam upaya 
peningkatan kecerdasan anak (Siswono, 2004).

Pada Mata kuliah asuhan neonatus bayi dan balita terdapat materi tentang stimulasi tumbuh kembang anak, diakhir pembelajaran dilaksanakan ujian praktik untuk mengaplikasikan materi tersebut. Berdasar pengamatan pada saat pelaksanaan Ujian Tahap II materi tersebut dimana pendidikan mendatangkan balita untuk dinilai tahap perkembangannya sesuai usia. Dari 64 balita 43 balita berusia 3-4 tahun. Sebagian besar (32 balita) bersikap kurang mandiri, masih tergantung pada orang tuanya, walaupun sudah mendapatkan mainan masing-masing tapi masih saling berebut, dan kurang merespon terhadap perintah yang diberikan. Padahal mereka sudah bersekolah (PAUD).

Berdasarkan latar belakang tersebut, penulis tertarik untuk melaksanakan penelitian sederhana tentang pengaruh jenis permainan edukatif dengan perkembangan sosial anak prasekolah usia 3-4 tahun.

\section{KAJIAN LITERATUR \\ PENGEMBANGAN HIPOTESIS}

DAN

Permainan edukatif merupakan permainan yang sangat memberikan fungsi permainan secara optimal dan perkembangan anak, dimana melalui alat permainan ini akan selalu mengembangkan kemampuan fisiknya, bahasa, kemampuan kognitifnya, dan adaptasi sosialnya (Alimul, 2005).

Tahapan Perkembangan Anak Usia 3-4 Tahun adalah : a. Mencoret-coret pensil pada kertas; b. Menyusun 4 kubus; c. Dapat melempar bola kearah dada atau perut; d. Bicara dengan baik, mengunakan 2 kata; e. Belajar mencium tangan dan mengeringkannya sendiri setelah makan; $f$. Dapat menunjuk 2 atau lebih gambar hewan; g. Membantu mengangkat piring sehabis makan; h. Mulai belajar mengotrol buang air besar dan buang air kecil/kencing (Depkes RI, 2007).

Sedangkan aspek perkembangan menurut BKB (Bina Keluarga dan Balita) adalah : a. Tingkah laku sosial; b. Menolong diri sendiri; c. Intelektual; d. Gerakan motorik halus; e. Komunikasi pasif; f. Komunikasi aktif; g. Gerakan motorik kasar (Soetjiningsih, 1995).
Dari umur 2 sampai 6 tahun anak belajar melakukan hubungan sosial dan bergaul dengan orang-orang diluar lingkungan rumah, terutama dengan anak-anak yang umurnya sebaya. Mereka belajar menyesuaikan diri dan bekerja sama dalam kegiatan bermain. Masa kanakkanak sejumlah hubungan yang dilakukan anak dengan anak-anak yang lain meningkat dan ini untuk menentukan bagaimana gerak maju perkembangan sosial mereka. (Elizabeth B Hurlock, 2002). Denver Development Screening Test adalah suatu metode skrining terhadap kelainan perkembangan anak, dengan aspek penilaian 125 tugas perkembangan, meliputi : a. Personal Sosial (perilaku sosial); b. Fine motor adaptive (gerakan motorik halus); c. Language (bahasa); d. Grass motor (Gerakan Motorik kasar).

Tes ini bukan untuk suatu diagnostik atau tes IQ sehingga tidak dapat meramalkan kemampuan intelektual dan perkembangan anak dimasa yang akan datang. Tes ini lebih mengarah kepada perbandingan kemampuan atau perkembangan anak dengan kemampuan anak yang lain yang seumurnya.

Bermain merupakan suatu aktifitas dimana anak dapat melakukan atau mempraktikkan ketrampilan, memberikan ekspresi terhadap pemikiran, menjadi kreatif, mempersiapkan diri untuk berperan, dan berperilaku dewasa. Dengan bermain anak dapat mengenal dunia, mampu mengembangkan kematangan fisik, emosional, dan mental sehingga akan membuat anak tumbuh menjadi anak yang kreatif, cerdas, dan penuh inovatif (Alimul, 2005).

Alat permainan merupakan salah satu alat untuk menstimulasi pertumbuhan dan perkembangan anak. Anak memerlukan alat permainan yang bervariasi, sehingga bila dia bosan permainan yang satu, dapat memilih permainan lainnya. Misalnya anakanak tidak hanya menghabiskan waktunya untuk bermain dengan pasir, balok, atau krayon saja, tetapi harus punya waktu walaupun sedikit untuk pertumbuhan otototot dengan bermain tali, bola, naik sepeda, dan lain-lain (Soetjiningsih, 1995).

\section{METODE PENELITIAN}

Desain penelitian yang digunakan adalah 
analitik korelasi dengan pendekatan cross sectional. Metode analitik korelasi pada penelitian ini digunakan untuk mengukur pengaruh permainan edukatif dengan perkembangan sosial anak prasekolah usia 3-4 tahun. Penelitian dilaksanakan di Pendidikan Anak Usia Dini (PAUD) Permata Hati Waru Sidoarjo yang telah menerapkan penggunaan Alat Permainan Edukatif (APE) dalam proses belajar mengajar dan belum pernah dilakukan penilaian secara khusus.

Dalam penelitian ini terdapat dua variabel yaitu variabel independent (penggunaan permainan edukatif) dan variabel dependent (perkembangan sosial anak). Proses pengumpulan data dilakukan dengan pengambilan data, antara lain data primer, data yang diperoleh dari pengajar dikelas yang berupa ceklist.

\section{HASIL DAN PEMBAHASAN}

Dalam pengambilan sampel yang dilakukan di Pendidikan Anak Usia Dini Permata Hati di dapatkan karakteristik responden berdasarkan umur sebagai berikut; 11 responden berumur 3 tahun (47,8\%), 12 responden berumur 4 tahun. (52,2\%). Dan berdasarkan jenis kelamin adalah sebagai berikut; sebagian besar jenis kelamin responden adalah perempuan $12(52,2 \%)$.

Dalam penelitian ini diketahui bahwa berdasarkan penilaian permainan edukatif, pada anak usia 3 tahun yang menggunakan permainan edukatif, dinilai mampu sebanyak 4 anak (17,4\%), cukup mampu 6 anak $(26,1 \%)$, dan kurang mampu 1 anak (4,3\%). Sedangkan yang usia 4 tahun mau melakukan permainan edukatif sesuai perintah, mampu sebanyak 5 anak (21,7\%), cukup mampu 5 anak $(21,7 \%)$ dan kurang mampu 2 anak $(8,7 \%)$. Dan dapat pula dapat diketahui berdasarkan perkembangan sosial anak prasekolah usia 3-4 tahun, anak usia 3 tahun berperilaku sosial sebanyak 7 anak $(30,4 \%)$, berperilaku tidak sosial 4 anak $(17,4 \%)$. Sedangkan yang usia 4 tahun berperilaku sosial sebanyak 8 anak $(34,8 \%)$, berperilaku tidak sosial 4 anak $(17,4 \%)$.

Berdasarkan data-data diatas dapat dilihat bahwa dari 23 anak usia 3-4 tahun, dilakukan menggunakan alat permainan edukatif dan dinilai menggunakan checklist, anak umur 3 tahun mampu melakukan, dan berperilaku sosial 4 $(17,4 \%)$, cukup 3 anak $(13,0 \%)$, kurang tidak ada. Umur 3 tahun dinilai mampu, tapi berperilaku tidak sosial tidak ada, cukup mampu tapi berperilaku tidak sosial 3 anak (13,0\%), kurang 1 (4,4\%). Sedangkan anak yang usia 4 tahun penilaian dengan permainan edukatif mampu dan berperilaku sosial 5 anak $(21,8 \%)$, cukup 3 anak (13,0\%), dan kurang tidak ada. Umur 4 tahun mampu melakukan tetapi berperilaku tidak sosial tidak ada, cukup 2 anak (8,7\%), kurang 2 anak (8,7\%). Dan jika data-data tersebut di analisis menggunakan korelasi product moment dengan taraf signifikasi sebesar 0,05 di dapatkan r-hitung sebesar 0,828 dan r-tabel 0,413 dengan jumlah responden 23 anak. Karena $r$-hitung $>$ dari r-tabel maka hipotesis yang telah disebutkan sebelumnya diterima, artinya ada pengaruh permainan edukatif dengan perkembangan sosial anak prasekolah usia 3-4 tahun di pendidikan anak usia dini Permata Hati Sidoarjo.

\section{KESIMPULAN}

Alat Permainan Untuk Anak Usia 3-4 Tahun bertujuan Mencari sumber suara, Melatih motorik halus dan kasar, melatih anak melakukan gerakan menarik dan mendorong, melatih imajinasi anak, melatih anak melakukan kegiatan seharihari semuanya dalam bentuk kegiatan yang menarik. Alat Permainan edukatif yang digunakan antara lain balok kubus, bola tenis/ plastik, buku gambar, krayon dan kartu.

Melalui bermain anak belajar sekaligus dapat melepaskan ketegangan yang di alaminya. Dengan bermain kelompok, anak akan mempunyai nilai terhadap dirinya tentang kelebihan yang dimiliki sehingga dapat membantu pembentukan konsep diri dan harga diri. Perilaku sosial anak usia 3-4 tahun dipengaruhi oleh beberapa hal, antara lain keluarga meliputi hubungan antar orangtua, antar saudara kandung, urutan anak dalam keluarga, jumlah keluarga, perlakuan keluarga terhadap anak, harapan orangtua terhadap anak. Karakteristik responden sebagian besar berperilaku sosial, hal ini bisa dilihat 
dari hasil penilaian indikator perilaku sosial anak. Responden mau berbagi, bisa bekerja sama, mau membantu temannya, mengikuti aturan, mau mendengarkan guru pengajar.

Anak-anak yang mengikuti pendidikan prasekolah melakukan penyesuain sosial yang lebih baik dibandingkan dengan anak-anak yang tidak mengikuti pendidikan prasekolah. Karena mereka dipersiapkan secara lebih baik untuk melakukan partisipasi yang aktif dalam kelompok dibandingkan dengan anak yang aktivitas sosialnya terbatas dengan anggota keluarga dan anak-anak dari lingkungan tetangga terdekat. Keuntungan pendidikan pra sekolah adalah memberikan pengalaman sosial dibawah bimbingan guru yang terlatih yang membantu mengembangkan hubungan yang menyenangkan dan berusaha agar anakanak tidak mendapat perlakuan yang mungkin menyebabkan mereka menghindari hubungan sosial.

\section{REFERENSI}

Alimul, Aziz.2011, Riset Keperawatan \& Teknik Penulisan IImiah:Jakarta, Salemba Medika.

Arifin, Z. 2010.Metodologi Penelitian Pendidikan Filosofi, Teori \&Aplikasinya, Surabaya, Lentera Cendikia.

Arikunto,S. 2010. Manajemen penelitian, Jakarta : Rhineka Cipta.

Depkes RI. 2006. Pedoman Pelaksanaan Stimulasi Deteksi dan Intervensi Dini Tumbuh Kembang Anak ditingkat Pelayanan Kesehatan Dasar, Jakarta.

Depkes RI. 2007. Stimulasi Deteksi dan Intervensi Dini Tumbuh Kembang Anak. Jakarta.

Dompas R. 2010. Buku Saku Bidan IImu Kesehatan Anak,Jakarta, EGC

Hurluck, EB. 2008. Perkembangan Anak Jilid. Surabaya, Erlangga.
Lucie permana sari, 2007. Pengaruh Permainan Edukatif terhadap motorik anak pada Taman Penitipan Anak. https://www.google.com/ pengaruh permainan edukatif terhadap motorik anak. Diunduh 20 Des 2013 pukul 13.00.

Rachmi maulana putri. 2012. Perkembangan Sosial Anak Usia Dini .

http://rachmimaulanaputri.blogspot. com/2012/11/perkembangan-sosialanak-usia-dini.htmldiunduh tanggal 20 Des 2013 Pukul 12.00.

Sekartaji, B. 2009. 101 Permainan Edukatif Untuk Anak. Jakarta. Pustaka Widyatama.

Soetdjiningsih. 2000. Tumbuh Kembang Anak, Jakarta : EGC .

Sorwono J. 2006. Metode Penelitian Kuantitatif \& Kualitatif, Graha IImu, Jakarta, 2006.

Sri nur Hasana, dkk, Jurnal e-NERS (eNS), Volume 1, Nomor 1, Maret 2013,

https://www.google.com/\#q=Pengar uh+permainan+edukatif+terhadap+ Aspek perkembangan+pada anak

Sugiyono, 2003. Statistik untuk Penelitian, Alfabeta, Bandung.

Yongki dan team.2012 Asuhan Pertumbuhan Kehamilan, Persalinan, Neonatus, Bayi dan Balita. Nuha Media. Yogyakarta. 